\title{
Conversations with Australian Indigenous Females Revealing Their Motives When Establishing a Sustainable Small Business
}

\author{
${ }^{*}$ Cecil A. L. Pearson ${ }^{1}$, Klaus Helms ${ }^{2}$ \\ ${ }^{1}$ School of Management Curtin University Perth, Western Australia \\ ${ }^{2}$ Gumatj Corporation Nhulunbuy, Northern Territory, Australia \\ *cecil.pearson@cbs.curtin.edu.au
}

\begin{abstract}
The Australian government has expressed commitment for Aboriginal entrepreneurship contending it is a pathway for ameliorating poverty, improving economic self-reliance, and building life quality. Yet a restrained geographic and sector spread of Australian Indigenous small business suggests there may be other important motives for starting an enterprise. This paper narrates responses from conversations with Aboriginal women ata remote settlement in the Northern Territory of Australia to reveal they were driven not by desires to acquire wealth, improve their educational opportunities or to escape poverty, but by practical aspirations of operating a local store selling household commodities used in daily living, a coffee shop meeting place, and to meaningfully change their existing community roles enabling them to 'get off welfare'. Documenting the experiences and expectations of these Indigenous women exposes how Aboriginal culture, family, and community socialising networks can contribute to fostering female entrepreneurship.
\end{abstract}

Key words: Indigenous; entrepreneurship; women; Gumatj; Australia

\section{Introduction}

The Australian government has expressed commitment for Aboriginal entrepreneurship as a pathway for greater economic prosperity, better health, and improved social well being of Indigenous people. A great deal of literature reveals Australian Indigenous people suffer from chronic poverty (Brotherhood, 2002; Homelessness, 2011), unsanitary living conditions (Pholi, Black \& Richards, 2009; Rowley, et al., 2008), relatively poor health (ABS, 2011; d'Abbs \& Maclean, 2008), and have greater incarceration rates (McGuirk, 2011) compared to the mainstream national society. These identified physiological and psychological issues continue to persist in spite of considerable investment by successive Australian governments. One prominent endeavour by the Australian Government to foster greater economic and community development has been to promote Indigenous entrepreneurship as a way for Aboriginal communities to reduce their socio economic disadvantage (Australian Government, 2007). Indigenous entrepreneurship has attracted a great deal of interest, but insights leading to sustainable pathways for these businesses are yet to emerge. A common thread within the literature is the notion of a homogenous people (Dana, 1995; Peredo, et al., 2004), and while relative simplistic perspectives are appealing and convenient to governments and practitioners the lack of rigour (Dunning, 2006) leads to generalisations and stereotyping regardless of ethnicity. Indeed, scant attention has been given to the extensive international managerial literature (Egbert, Fischer \& Bredl, 2011; Hofstede, 1980; Ralston, et al., 1997; Yeung, Warner \& Rowley, 2008), that has demonstrated concepts and practices of business are anchored in the contextual architecture of people, processes, structure and technologies. A lack of appreciation of these concepts has contributed to the serious level of disadvantage of Indigenous people. Indigenous contexts can be markedly different from one another as well as with the dominant mainstream society in which they are embedded. Neglecting these conditions limits opportunity for leveraging contemporary conceptual knowledge. In turn, this action reduces the potential to mitigate the persistently experienced chronic poverty, poorer education, and lower health quality of worldwide marginalised Indigenous populations (Altman, 2002; 2003; Maddison, 2008).

Yet assertions the phenomenon of Indigenous entrepreneurship is triggered by the perceptual opportunity to acquire economic independence or a belief involvement will lead to better relationships (e.g., quality of life and personal success) encourages governments and agencies to promote Indigenous commercial development with blanket/universal programmes for fostering Aboriginal small business (Australian Government, 2007; 2010a; Australian Taxation Office, 2009; Buultjens, et al., 2010; Wood \& Davidson, 2011). A failure to acknowledge a wide array of enterprise diversity (e.g., profit making, non profit, stand alone, community), and at the broad division of gender is irresponsible. Nominal 
acknowledgement is given to women yet they comprise a significant proportion of the population to which they make a substantial contribution. Consequently, the unique interests of these extremely different groups are not will served by inflexible programmes that inadequately deal with social, economic, and cultural circumstances (Hindle \& Moroz, 2009). Australian Government rhetoric for commitment to foster Indigenous entrepreneurship lacks diversity. In particular, the popularity of Australian Indigenous tourism has been constricted (Birdsall-Jones, Wood \& Jones, 2007) not only by a range of barriers (Russell-Mundine, 2007), but by the actions of public sector agencies administrating government policies devoid of sustainable development objectives (Whitford \& Ruhanen, 2010). A lack of capacity building in Indigenous enterprises is surprising given the considerable ongoing input from a number of social scientists (Adams, 2004; Choi \& Sirakaya, 2006; Dodson \& Smith, 2003; Hall \& Lew, 1998), who have acknowledged facilitating sustainable Australian Indigenous tourism encompasses economic aspects (i.e., profit), social factors (i.e., networks), and environmental dimensions (i.e., heritage, stewardship of land and sea resources). Yet Whitford and Ruhanen (2010) claim most government policies "... overtly focus on economic issues, arguably often at the expense of sociocultural and environmental issues." (p. 491). Support for this contention can be found in a recent report by the Australian Taxation Office (2009) in which environmental factors are neglected when promoting a pathway for Indigenous entrepreneurship creation. The absence of a more balanced approach in promoting pathways for successful Indigenous entrepreneurship is inexcusable given the comprehensive work done by Foley (2003; 2006a; 2006b; 2007; 2008; 2010) with Australian Aboriginals to observe extremities of enthusiasm for undertaking entrepreneurship.

Analysing Indigenous entrepreneurship endeavours has potential to contribute resolution of barriers and constraints to Australian Aboriginal enterprise. However, there have been few endeavours to record the non subjugated 'voice' of Indigenous entrepreneurs (Foley, 2007), especially women (Wood \& Davidson, 2011), and thus, the uniqueness of the presented material has importance for developing healthier more functional households and communities as outlined.

- Expand the knowledge base and research capability of successful Australian Indigenous entrepreneurship by demonstrating the relevance of factors other than profitability for the principal protagonist, financial viability, and book balancing of accounts.

- Identify critical aspirational features for encouraging Australian Indigenous entrepreneurship. In addition, particularly those attributes that can be attractive motivators for Aboriginal women.

- Build the confidence of to the Australian Indigenous women to embark on a career in entrepreneurship by providing them with a visionary framework developed by their counterparts.

- Influence Australian government policy makers to consider 'outside the box' aspects for enriching Indigenous training, education and social programmes as entrance requirements for starting a small business.

- Inspire and facilitate comprehensive investment within Australian Aboriginal affairs policy to enhance the construct of self determination in the pursuit of reducing the socio economic disadvantage experienced by Indigenous Australians.

More purposeful Australian Indigenous entrepreneurship will exhibit genuine commitment in collaborative frameworks that amalgamate economic, sociocultural, and environmental factors. Worldwide a growing labour participation rate of women has attracted considerable interest, but the female Australian Indigenous entrepreneurial literature remains underdeveloped (Wood \& Davidson, 2011). The purpose of this paper is to describe how the women of the Gumatj clan of the Yolngu Indigenous nation are embarking on a sustainable entrepreneurial venture. A key feature of the paper is to detail their strategic plan, which delineates how these women have addressed the identified economic and resource barriers of Australian Indigenous entrepreneurship. Through this process they have established a pathway for the economic and social development of their remote community at Gunyangara on the Gove Peninsula of the Northern Territory (NT) of Australia. Their contribution has potential to provide guidelines and confidence to other Australian Aboriginal women to enrich their communities by fostering entrepreneurship. The location of their venture is shown in Figure1.

[Put Figure 1 about here]

Regional Business Heritage: The region shown by Figure 1 has a rich business history. An extensive body of literature, often recounted by archaeologists, has made available knowledge of trade between the Macassans from the Celebes (Sulawesi) in the 17th century (Berndt \& Berndt, 1999; Ivory, 1999; Macknight, 1981; Russell, 2004). Other contributors are Alfred Searcy (1909), who was a customs officer in the late $19^{\text {th }}$ century, and Richard Trudgen (2000). Both of these commentators have recorded the 
nature of these business encounters in terms of trade for trepan (sea cucumbers), pearl shell and turtle shell in exchange for tobacco, axes, steel for spear heads and cloth material. Greater delineation of the size of the Macassan fleets of praus and the processing of the sea cucumber is to be found in the ship log of Investigator, captained by Matthew Flinders when he was in the region in 1803 while circum navigating Australia. Thus, the written records attest to the Yolngu being early Australian international traders for over 300 years until the South Australian Government (then responsible for administration of the land) cancelled the fishing licenses in 1907. Prior and subsequent to the Macassan trade the Yolngu practiced business concepts. Worsley (1955) and Rose (1987) recount that while the Aboriginal clans of Arnhem Land had traded among themselves this activity intensified with greater hunter efficiency (i.e., steel tools), and the teachings of the Macassans how to construct sea going dugout canoes. There was also some interaction with the early Dutch sailors following the sighting of land south of New Guinea in 1616 by Willem Janszoon in the Duyfken. Later, in 1623 two ships were commissioned by the East India Company to investigate trade potential, and when Willem Joosten Van Colster crossed the Gulf of Carpentaria (east to west) the land mass he sighted was named after his ship the Arnhem. Although the involvement of women in these social contacts seldom scored prominence females were the centre piece of the fostering of intensive Indigenous business from the beginning of the $20^{\text {th }}$ century for over 50 years. A prodigious Indigenous timber milling business in East Arnhem Land was rooted in the implication of Yolngu women. Japanese sailors, who also plundered the northern waters of Australia, were the essence of hostilities at Caledon Bay in 1933. Mistreatment of Indigenous women on the anchored ships led to the spearing death of five Japanese sailors by Indigenous men, and this spurred the Methodist Church to establish a further Mission at Yirrkala in 1935 (McKenzie, 1976; Shepherdson, 1981; Trudgen, 2000).

Establishing Mission stations at Milingimbi, Elcho Island, Yirrkala and Gapuwiyak sustained a commercial milling of cypress pine by Indigenous men, who were supervised by the missionaries. This industry flourished as the timber was resistant "...to terminates, indefatigable predators of other woods used for building." (Cawte, 2010). The Reverend Shepherdson commenced the timber business at Milingimbi in 1928 and later in 1942 on the Elcho Island, but by the 1970s, because of social, technological, and political reforms the milling of timber became an abstraction. There was, however, a short programme in the early 1980s when Indigenous men cut small diameter cypress pine logs at Gapuwiyak, and this timber was shipped to Kuri Bay in Western Australia for use in the pearl farming industry. While Indigenous women were on the periphery of the enterprise in addition to providing family support they were engaged in missionary medical and educational services. During the 1990s the Gumatj men reinvigorated the milling of timber on the Gove Peninsula. Their enterprise was the milling of NT stringy bark (eucalyptus tetrodonta), which is a hard wood, from the savannah forest on their ancestral land. Harvesting was undertaken in a region some $15 \mathrm{~km}$ west of Dhanaya and about $10 \mathrm{~km}$ north of the Gumatj cattle station at Garrathiya. Initially, the milled timber boards were used for the tops of bridges and tank stands as well as verandah floor boards. Later, in the mid 2000s a number of small entrepreneurial businesses gained traction when the Gumatj men intensified the timber milling and built a number of accommodation facilities (Pearson \& Helms, 2010a), and houses (Pearson \& Helms, 2010b), while dried timber was used to build quality furniture (Pearson \& Helms, 2011). Throughout this period the women provided important lesser conspicuous supporting roles within the social fabric of the clan. Rising above the customary profile of their place in the community the women have expressed an intention to become entrepreneurs. The female members of the Gumatj clan propose to operate profitable small businesses at Gunyangara. This remote outland Indigenous settlement is some $12 \mathrm{~km}$ west of the town of Nhulunbuy, that was established in the 1960s by the international mining corporation Northern Australian Bauxite and Alumina Company. The region of the Gove Peninsula has continued to attract the interest of mining companies for the rich deposits of bauxite ore that were exposed by the military when building the airport in the Second World War. Today, the isolated town of Nhulunbuy, which has all the facilities of a modern Australian town site (i.e., hospital, schools, police, emergency services) exists to provide the workforce for the mining operations, that are one of the biggest in the southern hemisphere. The town population of 4000 is mainly non Indigenous. Within proximity of Nhulunbuy is a similar size population of Indigenous Yolngu people who live in remote rural and regional settlements. Consequently, the Gumatj women enjoy confidence the reasonably close population as well as visitors (e.g., Garma Festival) will provide market opportunity for a local venture at Gunyangara.

\section{Gumatj Women's' Entrepreneurship Scaffolding}

Operating the Gunyangara entrepreneurial venture translates the Aboriginality of the Gumatj women. A significant shift from the policy of assimilation toward the concept of self determination and an attraction 
to Indigenous land rights (Anderson, 2007; Sanders, 2002; Smith, 2006) onset, in the 1970s, an exodus of Aboriginal people in the NT from missions and centralised town sites to small communities (i.e., outstations) on their ancestral lands (Altman, 2003). Gunyangara represents one of these outstations where the population fluctuates as people come and go as they exercise their traditional lifestyle of hunter gatherer pursuits (e.g., collecting art supplies, hunting, and fishing). Hence, at times the local inhabitants of Gunyangara may be elsewhere while other clan members from geographically dispersed communities will at times sojourn to Gunyangara, and may at that time become a working member in the business. These people movements are a reality of clan lifestyles in remote communities of the NT. To accommodate the traditional nomadic heritage and build flexibility into the employment arrangements encourages the training of a number of Indigenous women from which a daily cadre of employees will be rostered. While scheduling/mustering the daily personnel will be a challenge for the supervisor it is a novel form of job sharing, for which there is recent precedent. Indeed, when the Gumatj men built an architecturally designed timber building at Garrathiya (Pearson \& Helms, 2010a) the male elders organised a daily workforce from a much larger labour pool. A few of the total population of the Indigenous women were orally assessed to record a desire for the clan to establish a female entrepreneurial business. Traditionally, the views of the senior women are sought for their wisdom and experience. Authority from the clan apex is rooted in the distinctive socio cultural norms to enable the management of clan relationships so members can collaborate constructively, to build trust and avoid sensitive matters. Hence, only the elder Indigenous women were given a voice how the women of the clan would manage uncertainty, their time, and themselves. Consideration of uncertainty is important for exercising loyalty and obligation to group interests; while the attribute of time reflects patience to work in the future, which in the past has been pragmatic subsistence (Berndt \& Berndt, 1999; Johns, 2011; McKenzie, 1976; Shepherdson, 1981; Worsley, 1955); and deliberations about self management engenders self assertiveness for success and recognition.

These concepts have prominence in the social arrangements of remote Indigenous communities of the Gove Peninsula of the NT. Nevertheless, despite community involvement in decision making the final determination is made by the clan elder. This phenomenon is articulated by Pearson and Chatterjee (2010) in the case of an adult Gumatj male who wanted to adjust his work schedule to improve the well being of a handicapped brother, but was prohibited from commencing new work arrangements until approved by the leader. The notion of developing an Indigenous women's business at Gunyangara attracted responses aligned with community interfacing with a fundamentally different customary economic society as well as personal desires. Reconciling community centred commercial and economic development embraced a range of practical circumstances including the notion they wished to participate in the general economy on their own terms." (Peredo, et al., 2004). Voiced by the women was a belief the cattle station at Garrathiya would supply cryovaced chilled meat, that they (the women) could prepare in the existing commercial kitchens at Gunyangara. These wholesome meals could be sold to the community to provide an economic outcome. More important for the Indigenous people was these take away meals would be more healthy than the fast food, available in Nhulunbuy, that has been linked with endemic Indigenous health issues (i.e., diabetes, cardio vascular, renal failure) (Anglicare, 2009; Dockery, 2009; Rowley, et al., 2000). Hence, there was the realisation of a common good goal. Popularly endorsed was the need for mainline jobs in a community where few employment opportunities exist. Attaining sustainable vocations will enable the discarding of welfare (to which many Indigenous people are wedded) or government financially subsidised 'pretend jobs' (Pearson, 2007; Yunupingu, 2009), and the associated meaningless existence that is coupled with violence, alcoholism and self harm in the region (Midford, et al., 2011; Wilson, et al., 2010; Wurst, 2009). The interviewed women also believed the operation of an Indigenous women's business at Gunyangara would pull or push other community members (women and men) to seek employment. Establishing a local store has potential to provide a venue for selling art and crafts to develop the Gunyangara community, while being more convenient than having to travel to Nhulunbuy as the return taxi fare is $\$ 60$. The core element of the entrepreneurial proposal of the Gumatj women is to conduct a contemporary social business on their ancestral land employing clan resources not for personal economic gain, but to pursue a community good.

Project Underpinning: The female Gumatj entrepreneurial proposal is expressed as a strategic plan embracing a period of five years. Considerable delineation of the identified facets of the proposal is presented in 17, A4 pages that contain Tables, Figures and text to reveal the vision, key tangible objectives and prominent milestones (Gumatj Retail, 2011). A comprehensive level of analysis is given in terms of the time line of annual forecasts of categories of expenditure, predicted scales, and net revenue. 
The material shows for the first five years the venture is unlikely to make a profit, but there will be net positive social and financial outcomes.

Site: The study was undertaken in the locality of Gunyangara. Some of the senior Gumatj clan ladies were invited to meet with the authors and at their convenience small groups were convened. These sessions were held either on the beach or in the shade of trees with all members sitting on the ground, as is the traditional arrangement. It is not normal for non Indigenous people to enter Indigenous homes nor was the office Marngarr Community Government Council Office (at Gunyangara), or the training centre chosen as they were non neutral environments that were likely to restrict open discussion. These meetings disclosed an important element of the proposal is to create 15 full time jobs where currently no meaningful work opportunities exist. The respondents acknowledged as the required skills for the business venture are absent in the community of Gunyangara the initial major expenditure will be incurred with staff training, administrative management, the employment of supervisors to instruct Gumatj women in the supervisory role, and there will be a cost for incidentals (e.g., stationary, office equipment, uniforms). In addition, a business manager will be engaged to install and maintain appropriate systems of governance, to professionally administer the keeping of financial records, and to ensure full compliance with regulatory requirements (Russell-Mundine, 2007). In addition, one coordinator is to be employed to monitor the expenditure of government grants, to meet all funding obligations (e.g., submission of reports, auditing of financial statements), and to oversee all the training obligations., and the training will be given by two supervisors who will instruct three Indigenous Gumatj women to become supervisors, and give on the job training to another 25 Gumatj ladies. The respondents expect these Indigenous females will undertake work readiness programmes and learn bridging skills (i.e., cash register, sales, food safety) as well as completing various stages of Certificate 1 or 2 in retail management in the first 18 months of the venture. One salient target is to have three Indigenous Gumatj ladies trained as supervisors and another 11 Indigenous women in full time employment by the end of 18 months. A subsequent goal is to sufficiently develop commercial opportunities so that during the fourth year and the fifth year to be able to employ 15 Gumatj women in full time sustainable jobs.

\section{Method}

Respondents: Procedural arrangements of Indigenous meetings do not follow Western protocols. After introduction of the members and outlining the reason for the meeting the attending ladies were invited to explain their business proposal. Bilateral responses from an Indigenous lady to one of the authors was neither expected nor given, but what did occur was a number of conversations between the ladies in a 'free for all'. These conversations were in their mother tongue as the ladies engaged in a number of bilateral and more complex communication networks as they spoke between themselves to clarify the question and explore possible answers. After this intensity of oral interactions one senior lady would speak in English. The answers were brief, but pertinent and from a combination of several replies a robust foundation for their proposal was articulated. The main points made by the Indigenous ladies are listed.

- Our women are smart, educated, and want to work, but they are not many jobs.

- Our community is a $\$ 60$ taxi round trip to the nearest supermarket at Nhulunbuy.

- The food that is easy for us to prepare from the Nhulunbuy shops and consume is not healthy.

- We have a cattle farm but nowhere to sell our meat.

- We have a commercial kitchen at Gunyangara that is not being used.

- We have a nursery, but nowhere to sell our plants.

Two common threads emerged from the meetings. First, the Indigenous ladies acknowledged their community had a great deal of challenges and opportunities. Second, the women held a belief a retail store will enable them to address some of these issues, positively.

Procedure: Comments made by the Indigenous ladies were recorded and used to generate two written outputs. The first document was a 17 page report of figures and texts to provide a robust residual record of the provided details. A second written report was a formal request to the Federal Department of Education Employment and Workplace Relations (DEEWR) outlining the proposal and seeking Federal funding. Preparation of the documentation was undertaken by managerial and administrative personnel of the Marngarr Community Government Council Office, who were contracted by the Gumatj Corporation. The Gumatj retail venture is within the gambit of the Indigenous Employment Policy (IEP). This policy, which was implemented in July 1999 by the Australian Government in recognition of the particular 
disadvantage of Indigenous people in the Australian labour market, has three components that are associated with the Gumatj women proposal. First, there is the realisation the local people do have access to some business related capacity (e.g., land, people, market), but also there is a lack of a number of important entrepreneurial skills and business acumen (e.g., education, training, financial systems). Therefore, additional external personnel will be engaged to assist the pursuit of optimistic assumptions of the Gumatj female proposal. Second, given the strong underlying assumptions of the business proposition the notion is worthy of government financial assistance (Australian Government, 2007; 2010a). The funding would be used to hire appropriate people to manage the business and train Indigenous women in essential basic business competencies as well as how to build financial and administrative systems of governance. Last, as government financial assistance is limited to 18 months by the close of this period succession will need to be secured so the services of the IEP coordinator and the two supervisors can be terminated. Acknowledging Indigenous enterprises are vulnerable to succession is demonstrated as commitment by the Gumatj (men) Corporation to continue to fund the external business manager until a Gumatj female is qualified to professionally administer financial and governance systems of a sustainable retail business at Gunyangara.

\section{Analysis}

The written application to DEEWR for funding the Gumatj ladies proposal contains data for assessing the viability of the venture. Both the Australian Federal Government department of DEEWR, as well as Families and Housing Community Services and Indigenous Affairs (FAHCSIA) have capacity to fund Indigenous employment opportunities that have potential to reduce the disadvantages experienced by the Indigenous people. The proposal to establish an Indigenous female entrepreneurial venture at Gunyangara provided data for assessing the viability of the venture. The Indigenous venture proposal is likely to be attractive to DEEWR as well as FAHCSIA. Within the written application there are key features worthy of reporting. For example, for the first 18 months the required government funding has been calculated as \$703K (DEEWR, \$263K; FAHCSIA, \$195K; Indigenous Training Education Centre (ITEC), $\$ 245 \mathrm{~K}$ ), with a further $\$ 580 \mathrm{~K}$ supplement from two Indigenous groups (Gumatj Corporation, $\$ 480 \mathrm{~K}$; Marngarr, $\$ 100 \mathrm{~K}$ ). For the first five years the total costed expenditure is some $\$ 1.283$ million (i.e., employment of a business manager, training of 25 Indigenous women, full time employment of 11/15 Gumatj females). Additional contributions from the Gumatj Corporation $(\$ 730 \mathrm{~K})$ and Marngarr $(\$ 120 \mathrm{~K})$ will be the major funding after 18 months. Should the proposal not be adopted welfare payments to 15 Indigenous Gumatj women for five years will be $\$ 2.625$ million $(15 \times 5 \times \$ 35 \mathrm{~K})$. Even if there were nil sales by the proposed business, which is most unlikely, the financial betterment to the Australian taxpayers by adopting the proposal is $\$ 1.342$ million. Adoption of the business proposal has currency for the local Indigenous communities of Birritjimi, Galupa, Gunyangara, Nhulunbuy and Yirrkala in terms of enhanced socio economic outcomes of lower violence, less substance abuse, lesser poverty and an overall better quality of life.

Discussion: The entrepreneurial proposal by the Indigenous women that is detailed in this paper brings refreshing insights to the relevant literature. Distinctive challenges experienced by Australian Indigenous small business mostly “... run by men." (Wood \& Davidson, 2011: 312), have been reported in a relatively sparse literature, which has focussed on urban ventures (Australian Government, 2010a; Foley, 2006b; 2008), leaving the barriers and opportunities to Aboriginal entrepreneurship in remote regions of the nation even less understood. Australian governments, and particularly the Federal institutions, have recognised Indigenous entrepreneurship is uniquely different to Australian non Indigenous business (Altman, 2003; Blanch, 2008; Rola-Rubzen, 2011), which has been demonstrated by commitment within unparalleled policy leading to the provision of financial assistance and business support (Australian Government, 2007; Whitford \& Ruhanen, 2010). In spite of many programmes being installed seldom have they been aligned with Indigenous cultural and economic aspirations, that are fundamentally different to mainstream models, and consequently, over time few Australian Aboriginal enterprises have been sustainable (Furneaux \& Brown, 2008; Open for Business, 2008; Russell - Mundine, 2007). Championing an enterprise by Indigenous women opens alternative avenues for the economic and social development of remote Australian Aboriginal communities. In the traditional patriarchal Australian Indigenous clan there has been limited exposure of women members reframing customary social protocols and initiating systematic change to traditional practices (Foley, 2003; 2006a; McKenzie, 1976; Trudgen, 2000; Worsley, 1955). Nevertheless, there is precedence for Indigenous women on the Gove Peninsula to have cautiously implemented regional nurture flavoured solutions to complex social issues. For instance, in the early 2000s the Indigenous women were the instigators of the night patrol 
service for Birritjimi, Galupa, Gunyangara, Nhulunbuy and Yirrkala; a service that provides appropriate assistance to Indigenous males at risk (often from substance abuse). Less than a decade later the scheme has exploded to become administered and funded by the Department of the Attorney General, and coupled with legislation has led to the establishment of wide ranging care facilities in a number of major centres across the NT (Australian Government 2010b). Each night the Indigenous ladies drive the three collection vehicles in the Nhulunbuy region, within a framework of government regulations, while passively supported by the clan male members. The night patrol case and the Gunyangara proposal highlight the importance of being the perceived principal provider for both family and extended family, which are cultural beliefs about kinship obligations. This observation suggests family issues rather than commercial dimensions are intrinsic entrepreneurial motivators for Indigenous women, who are a minority group.

In spite of Australian Indigenous women entrepreneurs being under represented in the industry their contribution has importance to understand their motives for becoming self employed. Although steadily growing Australian Indigenous entrepreneurship is conveniently and loosely defined (Foley, 2006b, Whitford \& Ruhanen, 2010), and the roles played by women are rarely mentioned. Often the more prominent reported motives of Australian Indigenous entrepreneurs, who are mainly men, are couched in terms of overcoming poverty (Australian Taxation Office, 2009; Wood \& Davidson, 2011), to acquire economic independence (Australian Government, 2007; Foley, 2003; Furneaux \& Brown, 2008), or to enhance personal status (Australian Taxation Office, 2009; Foley, 2006b; Schaper, 2007). However, these objectives did not hold primacy with the interviewed Gumatj women, who expressed a strong preference for balancing community needs and obligations with new business demands (e.g., close shopping facilities, sustainable jobs for women, develop a local convenient retail centre). Interestingly, an almost identical set of motives, albeit 'hidden away' in the Report, was given by young Australian Indigenous women, who responded to members of the House of Representatives when inquiring how to develop Australian Indigenous entrepreneurship (Open for Business, 2008). The lack of partitioning evidence across gender exacerbates the social and political dominance of Indigenous females, and while this condition exists generating pathways for them to become successful entrepreneurs will remain problematic. The Gumatj women have proposed a business strategy to side step the reported barriers to Indigenous enterprise development. Reported in the relevant north American Indigenous literature is 1) the inability to engender in the community notions of self interest and economic behaviour, and 2) members ill prepared to become skilled in business financial knowledge, administrative systems, and practices of governance (Galbraith, Rodriguez \& Stiles, 2006; Peredo, et al., 2004; Simeone, 2007). Greater delineation of these identified obstacles to the entrepreneurial ambitions of Australian Indigenous people is to be found particularly in the tourism literature. Tourism has been promoted as a promising pathway for Australian Indigenous entrepreneurship (Australian Government, 2007; 2010a; Australian Taxation Office, 2009; Open for Business, 2008), the industry has attracted considerable enthusiasm from Aboriginal people, and in turn the relationship between tourism and Indigenous people has spawned a great deal of investigation. Although it is reported Australian Aboriginal participation in small business is relatively low a feature of the investigations is the identification of a number of factors that inhibit Indigenous entry to the Australian small business sector. Prominent nominated barriers are access to financial capital (Australian Taxation Office, 2009; Buultjens \& Fuller, 2007; Wood \& Davidson, 2011), acquiring the resources of people and land (Blanch, 2008; Furneaux \& Brown, 2008; Russell-Mundine, 2007), and building organisational infrastructure, business acumen as well as relevant education and workplace competencies (Altman, 2002; Foley, 2006b; Whitford \& Ruhanen, 2010).

Other specified limiting factors are market availability, industry linkages, managerial/supervisory skills and cultural dimensions such as discrimination. The proposal advanced by the Gumatj women reveals they were proactive to establish a platform for community expectations and family ties, essential for networking to the benefit of business development. Mindful the community lacked business education, industry experience, and there was an absence of managerial/supervisory skills they exercised the option to acquire funding and training services from government departments while aware of the supporting commitment of the men. Overall, resources of land, people, and finances as well as social capital were addressed in their proposal to optimise their success as entrepreneurs in a remote region of Australia. A salient feature of the Gunyangara retail development proposal is the allocated time for installing the venture. Funding and training support from Australian government departments is usually less than two years, and this limited period of assistance may explain why many new Indigenous ventures lack sustainability once the seed finance is expended (Buultjens \& Fuller, 2007; Foley, 2006b; Furneaux \& Brown, 2008; Wood \& Davidson, 2011). Under the rubric of Aboriginal self determination the Australian 
Government installed the Aboriginal and Torres Strait Islander Commission (1989) as the dominant government financier of Indigenous entrepreneurial activity. Despite considerable investment the institution was abolished in little over a decade because of a lack of stringent commercial eligibility requirements (Foley, 2006b; IBR, 2003; Sanders, 2002). Realising cultural demands can have primacy over prudent financial management objectives, yet they sought funding will attract stringent scrutiny of governance and compliance, the Gumatj women have chosen a more realistic five year timeline to accumulate sound commercial management skills within the business. Since conception of the desires of a small group of Indigenous women to operate a small business, in less than seven months several items of their proposal have been accomplished. Funding to initiate the enterprise has been acquired. With support from the men of the clan a coffee shop has been built where interested people can meet to further discuss these visions. Foundations for the retail store have been laid. The horticulture centre location is identified, security fencing has been erected, and a variety of flora products is in various states of development. A number of the Indigenous female ladies have enrolled in the next Ralpa education vocation programme, which is conducted with sponsors of 1) the mining company, and 2) the Charles Darwin University, and 3) the Technical and Further Education Department. This programme commences on $21^{\text {st }}$ May 2012. Although these factors demonstrate the Indigenous ladies have been active on a number of fronts the business venture is still in an embryonic stage and further evaluation is warranted to disclose the sustainability of participant enthusiasm and realisation of community expectations.

\section{Conclusion}

In spite of assertions entrepreneurship is a promising avenue for the social and economic development of Aboriginal community's Indigenous business remains relatively low in Australia. Commitment to brokering a better socioeconomic status of Australian Aboriginal people has been demonstrated in government policy, that has linked with departmental and agency publications as well as contributions of other stakeholders with a pecuniary stake in the evolution of successful Indigenous small business. Much of this material has been articulated in pretentious amorphous frameworks, predicated by a failure to integrate Indigenous diversity (e.g., gender), and consequently, has often been unqualified for addressing the unique challenges faced by the distinctly different Aboriginal contexts. In a versatile and proactive strategy the Gumatj women have dextrously attended the in congruencies acknowledged in the representative literature for Australian Indigenous small business. These women were inspired to pursue the pragmatic dimensions of a commodious market place and the utilitarian features it would bring to the community, and not the often promoted exotic ideals of escaping from poverty, having better economic independence, or achieving successful sufficiency, announced by paternal advocates. Moreover, the frequently recorded barriers were neutralised when the Gumatj females built on their complex cultural heritage of endowment, obligation, information channels, and social norms to allocate available capacity as well as attracting external supporters. The proposal, which is an initial step in the development of a new income generating market activity, in a remote Australian Indigenous region, has potential to encourage other Aboriginal groups to consider solutions to complex social and economic issues besetting their community. Establishing a small business in the remote settlement of Gunyangara is compelling the Indigenous women to venture into 'unchartered waters'. On the one hand their desire to improve the common good of their community is commendable, they can hold a belief the historical legacy of the business acumen of their forebears is likely to be embedded in existing social structures, support from external institutions, and the generous contributions from the clan men are assuring features. On the other hand the inseparable and integral cultural nuances exposing an ethos of sharing in broad ranging kinship systems manifests as clan members holding expectations of sharing housing, money and a wide range of commodities are disablers of the entrepreneurial process. Encouraging these individuals to change their mindsets of obligatory sharing is a serious challenge for Australian Indigenous entrepreneurs. At this time a number of important proposal milestones have been achieved by the contributions of a few clan members. Ongoing evaluation is warranted in this Greenfield site to better understand the fundamental interlacing of the commercial anchors and the cultural fabric of Australian Indigenous women entrepreneurs. 


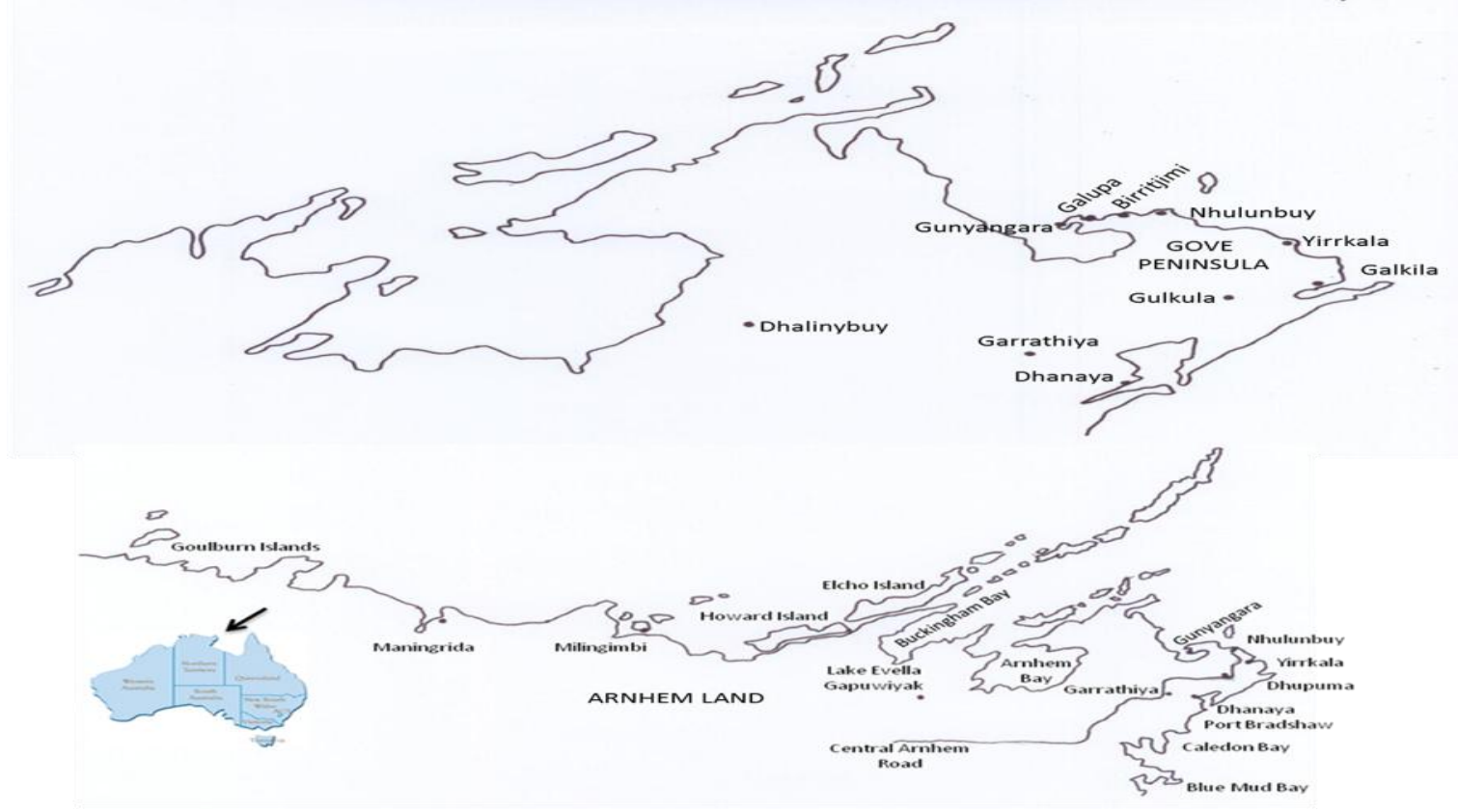

\section{References}

Adams, C. (2004). Triple bottom line reporting. Big picture: How the environment influences corporate profit, $47-47$.

Altman, J. (2002). Indigenous hunter - gatherers in the 21st century: beyond the limits of universalism in Australian social policy. In T. Eardley \& B. Bradbury (Eds.), Competing visions: Refereed proceedings of the National Social Policy Conference 2001, SPRC Report 1/02, and Sydney: Social Policy Research Centre, University of New South Wales, 35-44.

Altman, J. C. (2003). People on country healthy landscapes and sustainable Indigenous economic communities, The Arnhem Land case. The Drawing Board: An Australian Review of Public Affairs, $4(2), 65-82$.

Anderson, I. (2007). The end of Aboriginal self determination, Futures, 39(2/3), 137-154.

Anglicare, T. (2009). Gove Peninsula suicide mitigation 'working strategy' 2009, Developed as part of the Yuta - Walnga - suicide safer communities project, January - June 2009. Nhulunbuy, Northern Territory: Anglicare Northern Territory.

Australian Bureau of Statistics (ABS). (2011). Australian social trends. Retrieved from http://www.abs.gov.au/AUSSTATS/abs@nsf/Lookup/4102.0Main + Features10Mar+2 as on 17 October 2011.

Australian Government. (2010a). Indigenous economic development strategy: Draft for consideration and Action Plan 2010-2012, Canberra: Australian Government Printer.

Australian Government. (2010b). Night patrol services in the Northern Territory: Operational framework, Canberra: Attorney-General's Department.

Australian Government. (2007). Indigenous programs: Business and Employment. Retrieved from http://www.oeeo.wa.gov.au/documents/diversitybizz/past\%20articles/Indigenous\%20progra ms\%20Business\%20employment.pdfas on 1 September, 2009.

Australian Taxation Office. (2009). Indigenous small business owners in Australia. Canberra: Australian Taxation Office.

Berndt, R. M. \& Berndt, C. H. (1999).The world of the first Australians: Aboriginal traditional life past and present, Canberra: Aboriginal Studies Press.

Birdsall-Jones, C., Wood, D. \& Jones, R. (2007). Great expectations: Indigenous land based tourism in regional Western Australia. In J. Buultjens \& D. Fuller (Eds.), Striving for sustainability: Case studies in Indigenous tourism (187-209), Lismore, NSW: Southern Cross University Press.

Blanch, S. (2008). Steps to a sustainable northern Australia. Ecological Management and Restoration, 9(2), 110-115. 
Brotherhood, G. (2002). Facts, figures and suggestions for the future: Poverty Retrieved from www.bsl.org.au as on 17 October 2011.

Buultjens, J., Brereton, D., Memmott, P., Reser, J., Thomason, L. \& O’Rourke, T. (2010). The mining sector and Indigenous tourism development in Weipa, Queensland. Tourism Management, 31, 597-606.

Buultjens, J. \& Fuller, D. (2007). String for sustainability: Case studies in Indigenous tourism. Lismore, NSW: Southern Cross University Press.

Cawte, J. (2010). Healers of Arnhem Land, Marleston, Australia: Gecko Books.

Choi, H. C. \& Sirakaya, E. (2006). Sustainability indicators for managing community tourism. Tourism Management, 27, 1274-1289.

d'Abbs, P. \& Maclean, S. (2008).Volitile substance misuse: A review of interventions. Monograph Series No. 65, Barton, ACT: Department of Health and Ageing.

Dana, L. P. (1995). Entrepreneurship in a remote sub-Arctic community. Entrepreneurship Theory and Practice, 20(1), 57-72.

Dockery, A. M. (2009). Culture and wellbeing: The case of Indigenous Australians, Curtin Business School, Curtin University of Technology, Western Australia: Centre for Labour Market Research and School of Economics and Finance.

Dodson, M. \& Smith, D. E. (2003). Governance for sustainable development: Strategic issues and principles for Indigenous Australian communities, Canberra: CAEPR.

Dunning, J. (2006). New directions in international business research. Academy of International Business Insights, 6(2), 3-9.

Egbert, H., Fischer, G. \& Bredl, S. (2011). Different background - similar strategies: Recruitment in Tanzanian - African and Tanzanian - Asian companies. Journal of Entrepreneurship, 20(2), 189205.

Foley, D. (2003). An examination of Indigenous Australian entrepreneurs. Journal of Developmental Entrepreneurship, 8(2), 133-151.

Foley, D. (2006a). Does business success make you and less Indigenous?, Proceedings of the Conference on Regional Frontiers of Entrepreneurship Research 2006: $3^{\text {rd }}$ International Australian Graduate School of Entrepreneurship, Entrepreneurship Research Exchange, Auckland, New Zealand, 8-10 February, 2006, 241-257.

Foley, D. (2006b). Indigenous Australian entrepreneurs: Not all community organisations, not all in the outback, Canberra, The Australian National University: Centre for Aboriginal Economic Policy Research.

Foley, D. (2007). Do we understand Indigenous entrepreneurship? 2007 SEAANZ Conference Proceedings, Manukau City, New Zealand, 23-26 September.

Foley, D. (2008). Does culture and social capital impact on the networking attributes of Indigenous entrepreneurs? Journal of Enterprising Communities: People and Places in the Global Economy, 2(3), 204-224.

Foley, D. (2010). Enterprise and entrepreneurship are not un-Aboriginal. Journal of Australian Indigenous Issues, 13(4), 85-93.

Furneaux, C. W. \& Brown, K. A. (2008). Australian Indigenous entrepreneurships: A capital -based view. International Journal of Entrepreneurship and Innovation, 9(2), 133-144.

Galbraith, C. S., Rodrigues, C. L. \& Styles, C. S. (2006). False myths and Indigenous entrepreneurial strategies. Journal of Small Business and Entrepreneurship, 19(1), 1-22.

Gumatj Retail. (2011). Gunyangara retail development women's IEP and business plan. Gunyangara, Northern Territory: Gumatj Corporation.

Hall, C. M. \& Lew, A. (1998). Sustainable tourism: A geographic perspective. Harlow, UK: Addison Wesley Longman.

Hindle, K. \& Moroz, P. (2009). Indigenous entrepreneurship as a research field: Developing a definitional framework from the emerging canon. The International Entrepreneurship Management Journal, Retrieved from http://dx.doi.org/10.1007/s11365-009-0111-x as on 10 March 2010.

Hofstede, G. (1980). Culture's consequences. Newbury Park, CA: Sage.

Homelessness. (2011). Homeless and poverty. Retrieved from www.homlessnessaustralia.org.au as on 17 October 2011.

IBR. (2003). Report on support for Indigenous business. Canberra: Indigenous Business Review.

Ivory, B. (1999). Enterprise development: A model for Aboriginal entrepreneurs. South Pacific Journal of Psychology, 11(2), 62-71.

Johns, G. (2011). Aboriginal self determination: The Whiteman's dream. Ballan, Victoria: Connorcourt.

Macknight, C. C. (1981). Journal of a voyage around Arnhem Land in 1875. Aboriginal History, 5(2), 135144. 
Maddison, S. (2008). Indigenous autonomy Australian government's 'intervention' in Aboriginal communities. Australian Journal of Human Rights, 14(1), 41-61.

McGuirk, R. (2011). Aboriginal crisis: Some see 'no other way but jail', Retrieved from http://www.guardian.co.uk/world/feedarticle/9717125 as on 17 October 2011.

McKenzie, M. (1976). Mission to Arnhem Land. Sydney: Rigby Limited.

Midford, R., Maclean, S., Catto, M., Thomson, N. \& Debuyst, O. (2011). Review of volatile substance use among Indigenous people. Australian Indigenous Health Reviews, 6, 1-19. Retrieved from http://www.healthinfonet.ecu.edu.au/volatile - substance as on 17 October 2011.

Open for Business. (2008). Developing Indigenous enterprises in Australia. House of Representatives: Stranding Committee on Aboriginal and Torres Strait Islander Affairs, Canberra: Printing and Publishing Office.

Pearson, C. A. L. \& Chatterjee, S. R. (2010). Extending business education beyond traditional boundaries: A case study in negotiated problem resolution is a remote regional Indigenous community in Australia. Journal of Teaching in International Business, 21(4), 307-328.

Pearson, C. A. L. \& Helms, K. (2010a). Realising Indigenous entrepreneurial capacity: A case study of the Yolngu clan in a remote region of northern Australia. Global Business and Economics Review, 12(1/2), 72-84.

Pearson, C. A. L. \& Helms, K. (2010b). Building social entrepreneurship in a remote Australian Indigenous community: The East Arnhem Land housing construction case. Journal of Australian Indigenous Issues, 13(4), 2-18.

Pearson, C. A. L. \& Helms, K. (2011). Indigenous entrepreneurship in timber furniture manufacturing: The Gumatj venture in northern Australia. Information Management and Business Review, 2(1), 1-11.

Pearson, N. (2007). White guilt, victimhood and the quest for a radical centre. Griffith Review, 16, 3-58.

Peredo, A. M., Anderson, R. B., Galbraith, C. S., Hoing, B. \& Dana, L. P. (2004). Towards a theory of Indigenous entrepreneurship. International Journal of Entrepreneurship and Small Business, $1(1 / 2), 1-20$.

Pholi, K., Black, D. \& Richards, C. (2009). Is 'close the gap' a useful approach to improving the health and wellbeing of Indigenous Australians? Australian Review of Public Affairs, 9(2), 1-13.

Ralston, D. A., Holt, D. H., Terpstra, R. H. \& Yu, K. U. (1997). The impact of national culture and economic ideology in managerial work values: A study in the United States, Russia, Japan and China. Journal of International Business Studies, 28(1), 177-207.

Rola-Rubzen, M. F. (2011).The anatomy of the Australian entrepreneur: Understanding, micro, small and medium business entrepreneurs in Australia, Curtin University: Ninti One.

Rose, F. G. G. (1987).The traditional mode of production of the Australian Aborigines, Sydney: Angus and Robertson.

Rowley, K. G., Daniel, M., Skinner, K., Skinner, M., White, G. A. \& O’Dea, K. (2000). Effectiveness of a community - directed 'healthy lifestyle' program in a remote Australian Aboriginal community. Australian and New Zealand Journal of Public Health, 24(2), 136-144.

Rowley, K. G., O’Dea, K., Anderson, I., McDermott, R., Saraswati, K., Tilmouth, R., Roberts, I., Fitz, J., Wang, Z., Jenkins, A., Best, J. D., Wang, Z. \& Brown, A. (2008). Lower than expected morbidity and mortality for an Australian Aboriginal population: 10-year follow-up in a decentralised community. Medical Journal Australia, 188(5), 283-287.

Russell, D. (2004). Aboriginal -Makassan interactions in the eighteenth and nineteenth centuries in northern Australia and contemporary sea rights claims. Australian Aboriginal Studies, 1, 3-17.

Russell-Mundine, G. (2007). Key factors for the successful development of Australian Indigenous entrepreneurship, Tourism: Preliminary Communication, 55(4), 417-429.

Sanders, W. (2002).Towards an Indigenous order of Australian government: Rethinking self determination as Indigenous affairs policy, Canberra: Centre for Aboriginal Economic Policy Research: The Australian National University.

Schaper, M. (2007). Aboriginal and Torres Strait Islander entrepreneurship in Australia: Looking forward, looking back. In L.P. Dana \& R.B. Anderson (Eds.), International Handbook of Research on Indigenous Entrepreneurship, Cheltenham: Edward Elgar, 526-535.

Searcy, A. (1909).The Australian tropics. London: George Robinson and Co.

Shepherdson, E. (1981). Half a century in Arnhem Land, Terriers Park, South Australia: Panprint.

Simeone, T. (2007).The Harvard Project on American Indian economic development: Findings and considerations. Ottawa, Canada: Parliament of Canada.

Smith, A. (2006). Indigenous development - without community, without commerce. Australian Review of Public Affairs, 1-7. Retrieved from http://www.australianreview.net/digest/2006/09/smith.html as on 14 October, 2008. 
Trudgen, R. (2000).Why warriors lie down and die, Darwin, Australia: Aboriginal Resources and Development Services Inc..

Whitford, M. M. \& Ruhanen, L. M. (2010). Australian Indigenous tourism policy: Practical and sustainable policies? Journal of Sustainable Tourism, 18(4), 475-496.

Wilson, M., Stearne, A., Gray, D. \& Saggers, S. (2010). The harmful use of alcohol amongst Indigenous Australians. Australian Indigenous Health Reviews, 4, 1-19. Retrieved $\mathrm{http} / / / \mathrm{www}$.healthinfonet.ecu.edu.au/alcoholuse_reivew as 17 October 2011.

Wood, G. J. \& Davidson, M. J. (2011). A review of male and female Australian Indigenous entrepreneur. Gender in Management: An International Journal, 26(4), 311-326.

Worsley, P. M. (1955). Early Asian contacts with Australia. Past and Present, 7, 1-11.

Wurst, T. (2009). Suicide in North East Arnhem Land: An overview of suicide trends amongst the population of East Arnhem Land from January $1^{\text {st }} 2007$ to December 31 ${ }^{\text {st }} 2008$, Nhulunbuy, Northern Territory: Nhulunbuy Police Station.

Yeung, A., Warner, M. \& Rowley, C. (2008). Growth and globalisation: Evolution of human resource management practices in Asia. Human Resource Management, 47(1), 1-13.

Yunupingu, G. (2009). Tradition, truth and tomorrow, The Monthly, December 2008- January 2009, 3240. 